\title{
Impact of Bank Capital and Monetary policy on Lending Behavior of USA Banking Sector Before and After Global Financial Crises
}

\author{
Amna Kausar ${ }^{1}$, Chaudhry Abdullah Imran Sahi ${ }^{2}$
}

\section{Abstract}

This study investigates the impact of bank capital, capital structure and monetary policy on the lending behavior of USA banks before and after global financial crises. For this purpose, sample data is collected from the annual reports of top ten banks of USA from 2001 to 2017. A panel unit root is applied to check the stationarity of variables. In order to explain the impact of bank capital, capital structure and monetary policy on lending behavior of USA banks, fixed effect and random effect model have been used. The sample data has been divided into two sets. First data set is taken from 2001 to 2008 before financial crises. Second data set is taken from 2009 to 2017 after financial crises and all above tests have been applied on these data sets. Furthermore, in order to measure the lending behavior three types of lending have been selected lending to consumers, lending to real estate and lending to commercial $\&$ industrial sector of USA banks. In order to get the better picture of lending behavior of USA banks before and after financial crises: paired sample T-test has been applied on the data of lending before and after financial crises. Results of paired sample T-test showed there is significant difference in lending to consumers, lending to commercial \& industrial sector and lending to real estate before and after financial crises of USA banks because of the implementation of Basel III. So, we accept the alternative hypothesis for our second research que stion. Findings suggested that impact of bank capital, capital structure and monetary policy has significant impact on the lending behavior before and after the global financial crises with the positive change of sixteen percent in R-squared value. So, we accept the alternative hypothesis for our first research question. The results of coefficients shows that before financial crises (2001 to 2008) discounted interest rates have more significant impact on the lending made to consumers but after the global financial crises (2009 to 2017) discounted interest rates, capital structure and tier 1 capital ratio have more significant impact on the loan made to consumers. The results of coefficients shows that before the financial crises (2001 to 2008) discounted interest rates have more significant impact on the loan made to commercial and industrial sector but after the global financial crises (2009 to 2017) discounted interest rates, capital structure and tier 1 capital ratio have more significant impact on the loan made to commercial and industrial sector. The results of coefficients shows that before financial crises (2001 to 2008) discounted interest rates have more significant impact on the loan made to real estate but after the global financial crises (2009 to 2017) discounted interest rates and capital structure have more significant impact on the loan made to real estate. Findings of our study are aligned with Swamy (2015), who investigated the impact of bank capital on lending spreads and found that increase in capital ratio of banks would also increase their lending spreads. Our results are also matched with the findings of (Kosak et al., 2015), those concluded that capital structure significantly affect the loan growth of banks. Our results are also aligned with Chami \& Cosimano (2010), they found that change in monetary policy due to Basel Accord would lead to a change in bank capital and bank loans.

Keyword: Bank capital, Capital structure, Monetary Policy, Lending behavior, Basel accord, Basel III.

Banks are the financial institutions those deal in money and credit. Lending is a key function of the banks as when the first time in 1800 BC (in Babylon) the idea of banks began firstly, the moneylender made loans to the people. Bank health is closely related to lending activity. As providing loans are the way of banks to make money it is important to know about the elements that can have the direct impact on the lending behavior of the banks. This paper investigates the impact of bank capital, capital structure and monetary policy on lending behavior of banks. In past, many studies have been conducted on the bank capital and their lending behavior in many countries. But the researcher didn't find a study which investigated the impact of bank capital and the both capital structure and monetary policy on the lending behavior of USA banks before and after financial crises. Furthermore, this is the first study in which researcher did a comparative analysis of these variables before and after financial crises due to the change in Basel Accord.

Monetary policy has strongest impact on the lending behavior of the banks. It is enacted by the central banks that manage the money supply in an economy. The main purposes of this policy are to control inflation rate (between $2 \%$ to $2.5 \%$ ), reduce unemployment (below 6.5\%) and to promote long term interest rates. And the Federal Reserve's main purpose of enactive the monetary policy is to maintain the healthy economy growth that the $2 \%$ to $3 \%$ increase in the nation's gross domestic product. Monetary policy creates incentives for banks to loan and businesses to borrow. By monetary policy Federal Reserve regulations decides the growth of commercial banking industry. As it has major influence on the market interest rates, thereby affecting profit of the banks.

Bank capital represents the value of a bank's equity instruments that can absorb losses and it also helps the bank in times of

\footnotetext{
${ }^{12}$ School of Accountancy and Finance, The University of Lahore, Pakistan. Corresponding author: chabdullahsahi@yahoo.com
} 
liquidity crises. A bank's capital consists of Tier 1 and Tier 2 capital. Tier 1 capital includes shareholder's equity and retained earnings. This part of capital is clearly disclosed in the financial statements of banks and tier 1 capital is a primary indicator to measure a bank's financial health. Tier 2 capital consists of revaluation reserves, hybrid capital instruments (securities, convertible bonds with both debt and equity qualities) and general loan loss reserves etc. These undisclosed funds do not appear on bank's financial statements. Tier 2 capital is a supplementary capital because it is less reliable than tier 1 capital. It is more difficult to accurately measure due to its composition of assets that are difficult to liquidate. Banks having large amount of capital have more capacity to lend more (Schwert, 2018). Bank capital structure means how a bank finances its overall operations and growth by using different sources of funds. Capital structure is a mixture of equity and amount of debt. Debt comes in the form of bond issues or long-term notes payable. And equity is classified as common stock, preferred stock or retained earnings. Banks capital structure has also a strong effect on the bank lending behavior. Banks with more leverage in their capital structure have positive significant effect on their lending growth (Kosak et al., 2015).

Basel accord is the guidelines on regulatory standards formulated by the Basel committee on banking supervision (BCBS). The accord popularly known as "Basel accord on capital adequacy" is global capital measures and capital standards which require on how much capital a bank should have in place in relation to the risk. The BCBS has so far introduced a capital measurement system commonly referred to as Basel I, Basel II and Basel III, which seeks to improve the banking sector's ability to deal with financial stress, improve risk management and strengthen the bank's transparency.

Before the Financial crises of 2007-2008 Basel II was used to meet capital requirements for banks of capital adequacy ratio, tier 1 capital ratio, common equity ratio and leverage ratios in banks' capital. But because of the financial instability during the global financial crises the Basel committee has established the Basel III accord in which all these ratios have been increased to control the financial instability and to improve the quality of banking supervision all over the world. Banks must have the enough capital to absorb the negative shocks of the economy (Karmakar \& Mok 2015). All these ratios have the direct link with the lending behavior of the banks. Many papers have found poor effects of increased capital requirements on bank lending (Kashyap et al. 2010; Bridges et al, 2014).

\section{Research Objectives}

The objective of this research to examine the impact of bank capital, capital structure and monetary policy on the lending behavior of USA banks from 2001 to 2017. Second objective of this research is to conduct a comparative analysis of lending behavior of USA banks before and after the global financial crises because of the change in Basel Accord.

Following research questions developed in order to achieve the objectives of research

1. What is the impact of bank capital, capital structure and monetary policy on loan to Real Estate sector?
2. What is the impact of bank capital, capital structure and monetary policy on loan to consumers?

3. What is the impact of bank capital, capital structure and monetary policy on loan to commercial \& industrial sector?

4. Comparative analysis of lending to real estate before and after financial crises.

5. Comparative analysis of lending to consumers before and after financial crises.

6. Comparative analysis of lending to Commercial and industrial sector before and after financial crises.

This topic will be interest of wider audience including commercial banks, house sold borrowers, industrial and commercial borrowers as well as Government finance managers as lending played significant role in development of business sectors including industrial and commercial as well as real estate.

\section{Literature Review}

\section{Banks capital and lending}

Berrospide \& Edge (2010) examined the impact of banks capital on the lending behavior. The results indicated that the capital shortfalls and capital ratio shocks had modest effects on loan growth and had significant effect on real economy. Swamy (2015) analyzed the impact of capital requirement on lending spreads. The results indicated that increase in capital ratio of scheduled capital banks would increase their lending spreads. Obsorne et al., (2016) analyzed the relationship between bank capital and lending in good and bad times. Findings suggested that there was instability between the relationship of Bank capital, loan interest rates in good and bad times. Banks behave differently specially in financially crises. Schwert (2017) analyzed the relationship of banks capital and their lending behavior towards firms by taking the data of USA for the period of 1987 to 2012. Results showed that the well capitalized banks would lend more to these firms. Carlson et al., (2013) examined the impact of capital ratios on lending by making a comparison between differences in loan growth and differences in capital ratios. Findings showed that banks loan growth was high when capital ratio was low and loan growth was less when capital ratio was high. Drehamnn \& Gambocorta (2011) analyzed the effect of countercyclical capital buffer on bank lending behavior. The results showed that the countercyclical capital has the direct effect on bank lending with the excessive credit by banks. Park (2006) investigated the effect of possible stock undervaluation and the banks constrained capital requirement on bank lending in USA. The results indicated that the banks with low capital, high cost of capital and with tightened capital requirements has negative relation with lending opportunities of banks. Karmakar \& Mok (2015) examined the relationship between bank capital and their lending behavior by taking the sample data of medium sized commercial banks of USA. Our findings concluded that there was a modest impact of banks capital on their lending behavior. Akinyomi \& Enahoro (2014) analyzed the relationship between capitalization and lending behavior in Nigerian banking sector. The results revealed that the there is a positive but non-significant relationship between capital and the lending behavior of the banks. Francis and Osborne (2009) investigated the effects of bank capital requirements on the bank capital and its lending market in UK. The results concluded that higher target capital ratios set by the 
regulator authority (FSA) has the negative effect on the optimal loan growth of the banks. Labonne \& Lame (2014) examined the sensitivity of bank lending to Non-financial corporations to its regulatory capital requirements and the capital ratios. Findings revealed that the more supervisory capital constrained bank has the less sensitive credit growth which means regulatory capital requirements and capital ratios have the direct significant relation with the sensitivity of the bank's lending growth. Furfine (2001) investigated that how the banks adjusted their loan portfolios according to the bank capital requirements and the economic conditions. The study concluded that the increase in capital ratios would cause to decrease in loan growth and showed that the banks must adjust their loan portfolio to meet their capital requirements. Olokoyo (2011) examined the effect of commercial banks capital and the other factors on their lending behavior. Researchers discovered that the bank capital and their deposit have the direct impact on the bank lending behavior. Olumuyiwa et al., (2012) examined that how the lending behavior of commercial banks influenced by the capital and the other determinants of the banks of Nigeria. Findings of the study showed that capital and the lending behavior of the commercial banks of Nigeria have a positive significant relationship. Maurin \& Toivanen (2012) estimated the target capital ratios, lending portfolio's policy and holding of securities of the Euro area banks. Findings concluded that the adjustments for the higher equilibrium capital ratios effected positively and significantly to bank lending policy and the securities portfolios. Jokipii \& Milne (2008) analyzed the relationship between business cycle and the cross-country European banks capital buffers and their lending behaviors. Findings showed that there was a negative significant relation between capital buffers and the rate of GDP growth and the positive relation with the bank lending behaviors. Chu et al., (2018) examined the impact of bank capital on the loan availability in syndicated loan market of USA. Results concluded that the capital levels of banks participating in the syndicated loan were positively associated with the banks contributions to the loan. Kim \& Sohn (2017) examined whether the effect of bank capital on lending differs depending on the level of bank liquidity. Researchers found that bank capital has a significant positive effect on lending when banks retain enough liquid assets. This liquidity effect has remained during the recent financial crisis and was more important for large banks. The results suggested that bank capital and liquidity were complementary measures for increasing bank lending. Kishan \& Opiela (2000) study conducted in United States to examine the relationship of bank capital and lending behavior. The results indicated that bank asset size and bank capital have positive relation with loan growth, and they affect the ability of banks to raise funds and maintain loan growth during contractionary policy. Gambacorta \& Mistruli (2004) examined the impact of bank capital on their lending behavior. The results suggested that the banks with large capital have more opportunities to expand their loan portfolio. The effect of excess capital of banks has positive significant relation with banks' lending behavior. Narmeen et al., (2018) examined the importance of capital adequacy ratio for the bank capital, banks deposits and for the lending of the banks. Findings of the study showed that for banks it was important to maintain some specific amount of capital as capital reserves. Results finalized that the Capital adequacy ratio has direct impact on the change in capital and change in loans. Nicolo (2015) found a relatively small impact of an increase in capital requirements on lending and real activity both in the short and long-run. The results suggested that the negative short-run and long-run impact of an increase in capital requirements on bank lending and real activity is significantly larger than previously thought. Hamada (2017) examined the role of bank capital on the lending behavior of the banks. The results indicated that a wellcapitalized bank can increase its provisions of bank loans while still not responding to monetary policy, excepting non-forex banks. Gustavsson et al., (2017) examined the effects of capital requirements under capital regulators on the supply bank of bank loans to small and medium enterprises in Europe. Findings showed that 1 percent point increase in tier 1 capital ratio would decrease lending point by 1.24 percent.

\section{Capital structure with lending}

Kosak et al., (2015) examined the relationship between capital structure and loan growth and to analyze the role of quality of bank capital on lending channel. The results indicated that the banks with higher proportion of customer deposits and with higher tier 1 capital ratio had positive effects on bank lending behavior in all kind of circumstances. Lepetit et al., (2014) examined the bank capital structure adjustments and its effect on bank lending behavior. Results indicated that banks having more equity in their capital structure would do more lending. Mendez \& Gonzalez (2018) examined the influence of bank ownership and lending relationship on bank capital structure by taking the data of Spanish firms. Findings showed that bank ownership and lending relationship positively affected by the capital structure and had positive relation with debt maturity and negative relation with cost of debts. Because of this firms would easily add leverage in their capital structure. Cebenoyan \& Strahan (2004) examined the relation of capital structure and lending with active management through the loan sales market. The results suggested that the banks, those were more active and efficient in loan sales market have major quantity of leverage in their capital structure and did lend more. Leary (2009) identified the relation of capital market supply friction with bank capital structure and its effect on bank lending. The results finalized that due to the friction of capital market supply the ratio of debt has changed in a firm's capital structure. Change in capital structure has caused the changes in bank loan availability. Allen et al., (2011) analyzed that the amount of debt banks added in their capital structure and how it effects on the lending behavior of banks. Conclusion of study was that banks should added less amount of debt in their capital structure as the capital structure with less amount of debt has positive relation with lending. Ladime et al., (2013) investigated the determinants for lending behavior of banks in Ghana. Researchers concluded that bank capital structure and size have positive significant relationship with the bank lending behavior. It showed that the change in capital structure directly caused the change in bank loan growth. Akhtar et al., (2019) examined the effects of regulatory capital requirements and ownership structure on bank lending behavior in emerging markets. The findings showed that, in case 
of well-capitalized banks the interaction between the excess capital and monetary policy indicator has a significant positive relation with bank lending. In the case of bank ownership structure, banks with excess capital ratios and ownership concentration lead towards an increase in lending activity. Wu \& Yue (2006) investigated banks in China adjusted their capital structure in response to an increase in the corporate tax rate. The results indicated that these firms increased their leverage when the corporate tax rate increased and the banks with more leverage in their capital structure has better lending channel. Berger \& Udell (2002) examined the implications for the bank organizational structure, relationship lending and the availability of credit to small business. Researchers concluded that there was a positive significant relation between organizational structure and the relationship lending. And this positive relation has better for the availability of credit to small business. Amidu \& Hinson (2006) analyzed the relation among the capital structure, lending and the credit risk of the banks in their research. The results indicated that the when there was a one percent decrease of credit risk in Ghanaian banks then the eighty six percent debt was included in their capital structure and their lending rate was twenty eight percent. Pennachhi (1988) analyzed the effect of increase in cost of capital on the loan sales of the banks. This paper examined that what would be if banks buy loan from depositors and increase their capital by added some extra amount of debt in their capital structure and what would be the effect of this on loan sales. Findings concluded that the amount of debt (deposit) in bank capital structure has the positive impact on the loan sales of the banks.

\section{Bank Capital and lending with Monetary Policy}

Zicchino (2006) analyzed the relationship between monetary policy, bank capital and lending under Basel proposals (Basel II). The Results concluded that better macroeconomic conditions caused the increase in loan demand. But any shock in macroeconomic conditions (under Basel II) had not induced the banks to decrease their capital requirements. Shaw et al., (2013) examined the macroeconomic implications of capital adequacy requirement system on bank lending channel. Conclusion of this study was that the increase in the strength of bank capital requirements didn't reduce the equilibrium quantity of loans as the regulated monetary policy provided option of increase in capital accumulation instead of cutting back on lending. Disyatat (2011) investigated the impact of monetary policy on the deposits and the lending behavior of the banks. Results concluded that the strict monetary policy would drain the deposits from the banks and reduced the lending growth if there was any increase in banks uninsured liabilities. Gambacorta (2004) analyzed the lending behavior of banks with different changes in monetary policy. Conclusion of the study was that the banks with higher liquidity ratio were better able to protect their lending activities from the monetary policy shocks. Results showed that the $1 \%$ increase in repo rate would be caused the decrease in loan rate by $0.8 \%$. Cottarelli \& Kourelis (1994) explored the relation between financial structure and the level of bank lending rates and the bank lending rate differentials (money market rates). Results concluded that the transmission mechanism of monetary policy has the positive relation with the financial structure. And it showed that the lending rates would be different in different economic shocks. Ayuso et al., (2003) analyzed that the effect of macroeconomic policies on capital buffers and risk in lending of the banks of Spain. Results finalized that one percent increase in GDP growth would reduce the capital buffers by seventeen percent. Altunbas et al., (2004) explored the relation among the bank capital, bank lending and the monetary policy in the euro area. Findings showed that the monetary policy did differently effect to the banks having different degree of capital. Banks with least capital were more responsive to the change in monetary policy. Chami \& Cosimano (2010) investigated under Basel capital requirements, the effect of monetary policy on the bank capital and its lending behavior. The results showed that the change in Basel capital requirements and monetary policy would lead to a decline in the bank capital and the capacity of bank loans. Gambacorta \& Shin (2016) examined the value of bank capital for the monetary policy and for bank lending growth. Results indicated that rise in lending has association with high bank capital. It showed that there is a positive significant relation between bank capital and the lending behavior of the banks under better monetary policy. Heuvel (2002) examined the role of bank lending in the presence of capital adequacy regulation on the transmission of monetary policy. The results showed that the capital adequacy regulation increased the bank capital channel and the monetary policy affected the bank capital through which it could change the supply of loans of banks. Sengonul \& Thorbecke (2005) examined bank lending facing macroeconomic shocks. The study concluded that contractionary monetary policy implemented in Turkey puts limitations on the supply of bank loans. Thakor (1996) examined the relationship between capital requirements and bank lending under monetary policy. Findings showed that the increased in the capital requirement or in money supply could either increase the bank lending or reduced it, would depend on the structure of the monetary policy. Xiong (2013) focused on the role the bank lending channel in transmission of monetary policy in China. The findings suggested that central bank monetary policy asymmetrically affects bank lending behavior. Ghosh (2008) investigated the effects of monetary policy transmission on banking sector with the existence of capital regulation and presented how the monetary policy shocks effects the banks, deposits and their lending behavior. Findings showed that due to monetary contraction the constrained banks raised their loans to less risky borrowers. Results declared that the strict monetary policy has more negative impact on constrained banks' lending behavior because it was limiting their lending channel.

\section{Research Methodology}

In this section we discuss all details regarding the methods applied to measure the impact of banks capital, capital structure and the monetary policy on the bank lending behavior. It also explains the population, sample data, sources of data collection and all variables of this research.

\section{Theoretical Framework}

These theories are important to investigate the impact of bank capital, capital structure and monetary policy on the lending behavior of the banks. 
According to the Swamy (2015) that under Basel III proposal that increase in capital ratio of banks caused also increase in lending spreads of banks by taking the public and private bank group of India. Schwert (2018) refers the positive relationship between bank capital and lending by taking the different firms of USA. It also shows that the well capitalized banks would lend more to the firms. Kosak et al., (2015) inferred that the bank with funds of external sources have significant effect on loan growth by using the data of all banks of BRIC countries. Lepetit et al., (2014) also inferred that the banks having more equity in their capital structure would lend more. Cebenoyan \& Strahan (2004) inferred that the banks those were more active and efficient in loan sales market have major quantity of leverage in their capital structure and did lend more. Shaw et al., (2013) refers the monetary policy has the direct and positive significant effect on bank capital and its lending channel by using the different banks of Tiawan. Disyatat (2011) inferred that the strict monetary policy would drain deposits from banks and reduced the lending growth.

\section{Conceptual Framework}

This framework shows that these independent variables (bank capital, capital structure and monetary policy) have positive or negative impact on the loan made to real estate, loan made to consumers and loan made to commercial \& industrial sector of the banks. Capital adequacy ratio and Tier 1 capital ratio indicate the bank capital and discount interest rates represent the monetary policy of USA.

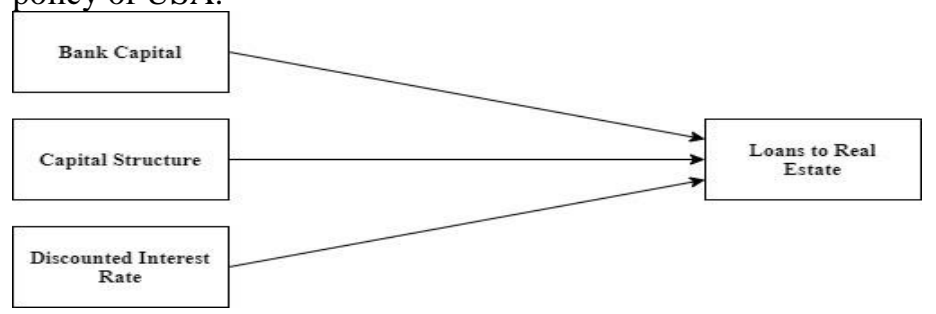

Figure 1: Conceptual Framework
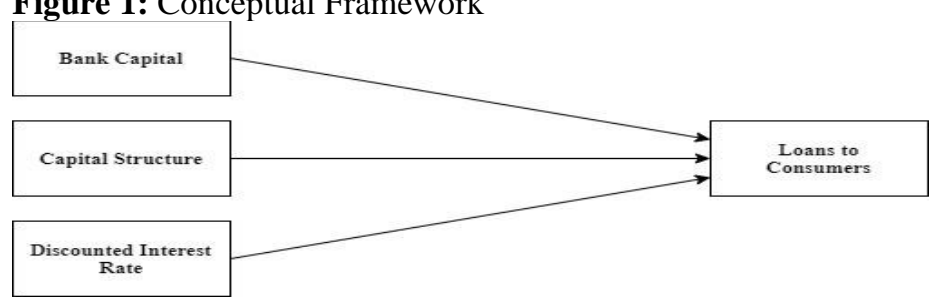

Figure 2: Conceptual Framework

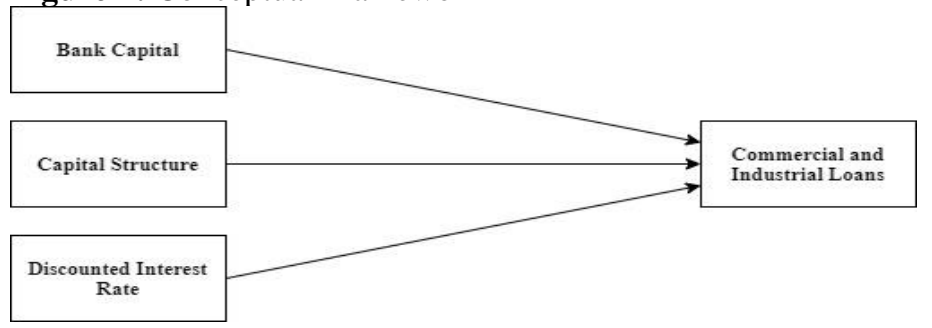

Figure 3: Conceptual Framework

Research Objectives

The first objective of the study is to investigate the impact of bank capital, capital structure and monetary policy on the lending behavior of the banks of USA from 2001 to 2017.
The second objective of the study is to differentiate the lending behavior of USA banks before and after financial crises from 2001 to 2017.

Research Hypothesis with Research questions

Q 1: Impact of bank capital, capital structure and monetary policy on loan to Real Estate sector?

$\mathbf{H}_{1}$ : There is a significant impact of bank capital, capital structure and monetary policy on loan to real estate sector.

Q 2: Impact of bank capital, capital structure and monetary policy on loan to consumers?

$\mathbf{H}_{1}$ : There is a significant impact of bank capital, capital structure and monetary policy on loan to consumers

Q 3: Impact of bank capital, capital structure and monetary policy on loan made to commercial \& industrial sector?

H1: There is a significant impact of bank capital, capital structure and monetary policy on loan made to commercial \& industrial sector

Q 4: Comparative analysis of lending to real estate before and after financial crises?

$\mathbf{H}_{1}$ : There is significant difference between lending to real estate before financial crises and lending to real estate after financial crises

Q 5: Comparative analysis of lending to consumers before and after financial crises?

H1: There is significant difference between lending to consumers before financial crises and lending to consumers after financial crises

Q 6: Comparative analysis of lending to Commercial and industrial sector before and after financial crises?

$\mathbf{H}_{1}$ : There is significant difference between lending to commercial $\&$ industrial sector before financial crises and lending to commercial \& industrial sector after financial crises

\section{Description of data}

Secondary data is used in the study. The data was collected from the Financial Statements and Administrative Reports of USA banks. The annual reports are collected from the bank's official websites, annualreports.com and from the website of Federal Reserves of USA. Sample is consisting of top 10 largest banks of United States of America according Assets, covering 17 years period (2001-2017).

\section{Description of Variables}

Our independent variables are bank capital, capital structure and monetary policy. To measure the bank capital (as Researchers karmakar \& mok 2013) we also used the capital adequacy ratio and tier 1 capital ratio. And to measure the monetary policy (as cottarelli \& kourelis 1994) we also used the discounted interest rates. And for capital structure (as cebenoyan \& strahan 2004) did we also use a formula to determine the capital structure ratio.

Capital/Risky assets $=$ Book value of equity / (Total assets - Cash - Fed funds sold - Securities)

Lending behavior of banks is our dependent variable. To determine the impact of bank capital, capital structure and monetary policy on lending behavior we focused on the three major sectors in the lending portfolios (as Hancock et al. 1995) did. Loan made to Real estate sector, Loan made to commercial and industrial sectors and loan made to consumers. 


\section{The Model}

A unit root test tests whether a variable is non-stationary and possesses a unit root. In this research to check the data stationarity unit root test is used.

The Hausman test is used to check which model is more appropriate between fixed effect and random effect in their studies. There is no correlation existing among dependent and independent variables both models fixed and random are consistent but fixed model are inefficient. Similarly, if there are correlation among dependant and independent variables, in this case the random effect model is inconsistent and fixed effect model is consistent.

The Hausman test is basically the difference between random and fixed effect.

$\boldsymbol{\beta}_{\mathbf{R E}}-\boldsymbol{\beta}_{\mathbf{F E}}$.

In fixed effect model the assumption is that the individual-specific effects are correlated with the independent variables. This model is also called LSDV estimator. The LSDV stands for least square dummy variables.

The estimate equations for our research are written as following: $\mathrm{LTC}_{\mathrm{it}}=a_{i}+\beta_{1} \mathrm{TR} 1_{\mathrm{it}}+\beta_{2} \mathrm{CAR}_{\mathrm{it}}+\beta_{3} \mathrm{CS}_{\mathrm{it}}+\beta_{4} \mathrm{DIR}_{\mathrm{it}}+\varepsilon_{\mathrm{it}}$

LTC\& $\mathrm{I}_{\mathrm{it}}=a_{i}+\beta_{1} \mathrm{TR} 1_{\mathrm{it}}+\beta_{2} \mathrm{CAR} \mathrm{R}_{\mathrm{it}}+\beta_{3} \mathrm{CS} \mathrm{Sit}_{\mathrm{it}}+\beta_{4} \mathrm{DIR}_{\mathrm{it}}+\varepsilon_{\mathrm{it}}$

$\mathrm{LTRE}_{\mathrm{it}}=a_{i}+\beta_{\mathrm{T}} \mathrm{TR}_{1 \mathrm{it}}+\beta_{2} \mathrm{CAR}_{\mathrm{it}}+\beta_{3} \mathrm{CS}_{\mathrm{it}}+\beta_{4} \mathrm{DIR}_{\mathrm{it}}+\varepsilon_{\mathrm{it}}$

In random effect model the assumption is that the individualspecific effects are uncorrelated with the independent variables. The random effect is more effective as compare to fixed effect model. Because random effect model has few parameters as compare to fixed effect to estimate. The random model also allows adding up more explanatory variables and gives them equal value. The estimate equations for our research are written as following:

$\mathrm{LTC}_{\mathrm{it}}=a_{i}+\beta_{1} \mathrm{TR}_{1 \mathrm{it}}+\beta_{2} \mathrm{CAR}_{\mathrm{it}}+\beta_{3} \mathrm{CS}_{\mathrm{it}}+\beta_{4} \mathrm{DIR}_{\mathrm{it}}+\varepsilon_{\mathrm{it}}$

LTC\&Iit $=a_{i}+\beta_{1}$ TR $1_{\mathrm{it}}+\beta_{2} \mathrm{CAR} \mathrm{R}_{\mathrm{it}}+\beta_{3} \mathrm{CS} \mathrm{Sit}_{\mathrm{it}}+\beta_{4} \mathrm{DIR} \mathrm{R}_{\mathrm{it}}+\varepsilon_{\mathrm{it}}$

$\mathrm{LTRE}_{\mathrm{it}}=a_{i}+\beta_{1} \mathrm{TR} 1_{\mathrm{it}}+\beta_{2} \mathrm{CAR}_{\mathrm{it}}+\beta_{3} \mathrm{CS}_{\mathrm{it}}+\beta_{4} \mathrm{DIR}_{\mathrm{it}}+\varepsilon_{\mathrm{it}}$

Researchers used t-test to determine if there is a significant difference between the means of two groups, which may be related in certain features. In calculating a t-test requires three key data values. They include the difference between the mean values from each data set, the standard deviation of each group, and the number of data values of each group. In this study, a paired sample t-test has been used. A paired sample t-test is used to compare two population means where we have two samples in which observations in one sample can be paired with the observations in the other sample.

$\mathbf{t}=\sum\left(\mathbf{X}_{1}-\mathbf{X}_{2}\right) / \mathbf{S E}_{\text {diff }}$

$\mathbf{t}=$ paired $\mathbf{t}$-test value

$\mathbf{S E}$ diff $=$ difference of the two data sets

Data Analysis

Analysis before global financial crises

Table 1: Loan to consumers (Hausman test)

\begin{tabular}{lccc}
\hline & Chi-sq statistic & Chi-sq d.f & Prob. \\
\hline Cross section random & 3.846010 & 4 & 0.4272 \\
\hline
\end{tabular}

According to the Hausman test the probability value is more than five percent so it means we accept the alternative hypothesis $\left(\mathbf{H}_{1}\right)$ which is the fixed-effect model is appropriate. And reject the null hypothesis for our discussed dependent variable loan to consumers before the global financial crises.

\begin{tabular}{llll}
\hline Cross section Fixed (Dummy variables) & & \\
\hline R-squared & & 0.725455 & \\
Prob(F-statistic) & & 0.000000 & \\
\hline & & & \\
\hline Variables & Coefficient & T-statistics & Prob* \\
\hline C & -45623.39 & -0.498659 & 0.6197
\end{tabular}

Capital adequacy ratio

Tier 1 capital ratio

Capital structure

Disc Interest rates

2779.908
4339.623
2648.043

12916.24

0.206301
0.315151
0.737517

2.907249

0.8372

0.7536

0.4634 0.0050

In fixed effect the discounted interest rates have the probability value less than the critical value $(5 \%)$ which means this is more significant variable for the loan made to consumers. R-squared value of fixed effect shows that these independent variables have more than seventy percent effect on the loan to consumers. Prob (F-statistics) value 0.000000 is showing that under fixed effect

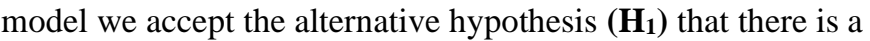
significant impact of bank capital, capital structure and monetary policy on the loan to consumers before the global financial crisis.

Table 2: Loan to Commercial and Industrial (Hausman test)

\begin{tabular}{lccc}
\hline & Chi-sq statistic & Chi-sq d.f & Prob. \\
\hline Cross section random & 2.960555 & 4 & 0.5644 \\
\hline
\end{tabular}

According to the Hausman test the probability value is more than five percent so it means we accept the alternative hypothesis $\left(\mathbf{H}_{1}\right)$ which is the fixed-effect model is appropriate. And reject the null hypothesis for our discussed dependent variable loan made to commercial and industrial before the global financial crises.

\begin{tabular}{|c|c|c|c|}
\hline \multicolumn{4}{|c|}{ Cross section Fixed (Dummy variables) } \\
\hline R-squared & & & 0.806978 \\
\hline Prob(F-statistic) & & 0000 & \\
\hline Variables & Coefficient & T-statistics & Prob* \\
\hline $\mathrm{C}$ & -46719.80 & 117238.6 & 0.6915 \\
\hline Capital adequacy ratio & 14757.78 & 17266.97 & 0.3958 \\
\hline Tier 1 capital ratio & -7534.500 & 17644.94 & 0.6708 \\
\hline Capital structure & 2374.773 & 4600.870 & 0.6075 \\
\hline Disc Interest rates & 10978.78 & 5692.990 & 0.0581 \\
\hline
\end{tabular}

Prob. (F-statistics) value 0.000000 is showing that under fixed effect model we accept the alternative hypothesis $\left(\mathbf{H}_{1}\right)$ that there is a significant impact of bank capital, capital structure and monetary policy on the loan made to commercial \& industrial sector before the global financial crises. R-squared value of fixed effect shows that these independent variables have eighty percent effect on the loan to commercial and industrial sector

Table 3: Loan to Real Estate (Hausman test)

\begin{tabular}{lccl}
\hline & Chi-sq statistic & Chi-sq d.f & Prob. \\
\hline Cross section random & 4.047418 & 4 & 0.3996 \\
\hline
\end{tabular}

According to the Hausman test the probability value is more than five percent so it means we accept the alternative hypothesis $\left(\mathbf{H}_{1}\right)$ which is the fixed-effect model is appropriate. And reject the null hypothesis for our discussed dependent variable loan made to real estate before the global financial crises.

\begin{tabular}{|c|c|c|c|}
\hline \multicolumn{4}{|c|}{ Cross section Fixed (Dummy variables) } \\
\hline R-squared & & 172 & \\
\hline Prob(F-statistic) & & 000 & \\
\hline Variables & Coefficient & T-statistics & Prob* \\
\hline $\mathrm{C}$ & 42796.67 & 0.424221 & 0.6728 \\
\hline Capital adequacy ratio & 1718.251 & 0.115644 & 0.9083 \\
\hline Tier 1 capital ratio & 4626.811 & 0.304729 & 0.7615 \\
\hline Capital structure & -2317.343 & -0.585333 & 0.5603 \\
\hline Disc Interest rates & 10836.96 & 2.212176 & 0.0304 \\
\hline
\end{tabular}

Prob (F-statistics) value is (0.000000) shows that under fixed effect model we accept the alternative hypothesis $\left(\mathbf{H}_{1}\right)$ that there is a significant impact of bank capital, capital structure and monetary policy on the loan made to real estate before the global financial crises. R-squared value of fixed effect shows that these independent variables have more than seventy percent effect on the loan to real estate. Discounted interest rate has positive and 
significant impact on loan to real estate sector before global financial crisis.

Analysis after global Financial Crises

Table 4: Loan to consumers (Hausman test)

\begin{tabular}{lccc}
\hline & Chi-sq statistic & Chi-sq d.f & Prob. \\
\hline Cross section random & 0.000000 & 4 & 1.0000 \\
\hline
\end{tabular}

According to the Hausman test the probability value is more than five percent so it means we accept the alternative hypothesis $\left(\mathbf{H}_{1}\right)$ which is the fixed-effect model is appropriate. And reject the null hypothesis for our discussed dependent variable loan to consumer after global financial crises.

\begin{tabular}{|c|c|c|c|}
\hline \multicolumn{4}{|c|}{ Cross section Fixed (Dummy variables) } \\
\hline R-squared & 0.8512 & & \\
\hline Prob(F-statistic) & 0.0000 & & \\
\hline Variables & Coefficient & T-statistics & Prob* \\
\hline $\mathrm{C}$ & 255492.4 & 6.613628 & 0.0000 \\
\hline Capital adequacy ratio & 6460.457 & 1.580814 & 0.1181 \\
\hline Tier 1 capital ratio & -13510.91 & -2.503289 & 0.0145 \\
\hline Capital structure & -4564.021 & -2.405856 & 0.0186 \\
\hline Disc Interest rates & 39832.25 & 2.362996 & 0.0207 \\
\hline
\end{tabular}

In the fixed effect the discounted interest rates, capital structure and tier 1 capital ratio have the probability value less than the critical value (5\%) which means these are more significant variables for the loan made to consumers. R-squared value of fixed effect shows that these independent variables have more than eighty five percent effect on the loan made to real estate. Prob (Fstatistics) value is $(0.000000)$ shows that under fixed effect model we accept the alternative hypothesis $\left(\mathbf{H}_{1}\right)$ that there is a significant impact of bank capital, capital structure and monetary policy on the loan made to consumers after the global financial crises.

Table 5: Loan to commercial \& industrial (Hausman test)

\begin{tabular}{lccc}
\hline & Chi-sq statistic & Chi-sq d.f & Prob. \\
\hline Cross section random & 0.000000 & 4 & 1.0000 \\
\hline
\end{tabular}

According to the Hausman test the probability value is more than five percent so it means we accept the alternative hypothesis $\left(\mathbf{H}_{1}\right)$ which is the fixed-effect model is appropriate. And reject the null hypothesis for our discussed dependent variable loan made to commercial and industrial sector after the global financial crises.

\begin{tabular}{|c|c|c|c|}
\hline \multicolumn{4}{|c|}{ Cross section Fixed (Dummy variables) } \\
\hline R-squared & & & 0.881436 \\
\hline $\operatorname{Prob}(\mathrm{F}$-statistic) & & & 0.000000 \\
\hline Variables & Coefficient & T-statistics & Prob* \\
\hline $\mathrm{C}$ & 28815.56 & 0.595917 & 0.5530 \\
\hline Capital adequacy ratio & -8497.421 & -1.661123 & 0.1008 \\
\hline Tier 1 capital ratio & 14458.04 & 2.140095 & 0.0356 \\
\hline Capital structure & 6792.282 & 2.860454 & 0.0055 \\
\hline Disc Interest rates & 82001.28 & 3.886387 & 0.0002 \\
\hline
\end{tabular}

In the fixed effect the discounted interest rates, capital structure and tier 1 capital ratio have the probability value less than the critical value $(5 \%)$ which means these are more significant variables for the loan made to commercial \& industrial sector. Rsquared value of fixed effect shows that these independent variables have eighty eight percent effect on the loan made to commercial \& industrial sector. Prob (F-statistics) value is (0.000000) shows that under fixed effect model we accept the alternative hypothesis $\left(\mathbf{H}_{1}\right)$ that there is a significant impact of bank capital, capital structure and monetary policy on the loan made to commercial \& industrial sector after the global financial crises.

Table 6: Loan to Real Estate (Hausman test)

\begin{tabular}{lll} 
Chi-sq statistic & Chi-sq d.f & Prob. \\
\hline
\end{tabular}

\begin{tabular}{llll}
\hline Cross section random & 0.000000 & 4 & 1.0000 \\
\hline
\end{tabular} According to the Hausman test the probability value is more than five percent so it means we accept the alternative hypothesis $\left(\mathbf{H}_{1}\right)$ which is the fixed-effect model is appropriate. And reject the null hypothesis for our discussed dependent variable loan made to real estate after global financial crises.

\begin{tabular}{|c|c|c|c|}
\hline \multicolumn{4}{|c|}{ Cross section Fixed (Dummy variables) } \\
\hline R-squared & & & 0.852579 \\
\hline Prob(F-statistic) & & & 0.000000 \\
\hline Variables & Coefficient & T-statistics & Prob* \\
\hline $\mathrm{C}$ & 218124.3 & 3.930941 & 0.0002 \\
\hline Capital adequacy ratio & -4099.699 & -0.698394 & 0.4871 \\
\hline Tier 1 capital ratio & 6443.494 & 0.831148 & 0.4085 \\
\hline Capital structure & -5372.498 & -1.971646 & 0.0523 \\
\hline Disc Interest rates & 52979.09 & 2.188081 & 0.0317 \\
\hline
\end{tabular}

In the fixed effect the discounted interest rates and capital structure have probability value less than the critical value $(5 \%)$ which means these are more significant variables for the loan to Real Estate. R-squared value of fixed effect shows that these independent variables have eighty five percent effect on the loan made to real estate. Prob (F-statistics) value is $(0.000000)$ shows that under fixed effect model we accept the alternative hypothesis (H1) that there is a significant impact of bank capital, capital structure and monetary policy on the loan made to real estate after the global financial crises.

\section{Comparative analysis of before and after global financial} crises

Table 7: Loan to consumers

\begin{tabular}{lllll}
\hline Variables & $\begin{array}{l}\text { Before financial crises } \\
(\mathbf{2 0 0 1 - 2 0 0 8 )} \\
\text { Fixed effect } \\
\text { Model }\end{array}$ & $\begin{array}{l}\text { Random } \\
\text { effect } \\
\text { Model }\end{array}$ & $\begin{array}{l}\text { After financial crises } \\
\mathbf{( 2 0 0 9 - 2 0 1 7 )} \\
\text { Fixed } \\
\text { effect } \\
\text { Model }\end{array}$ & $\begin{array}{l}\text { Random } \\
\text { effect Model }\end{array}$ \\
\hline $\begin{array}{l}\text { Capital adequacy } \\
\text { ratio }\end{array}$ & 0.8372 & 0.8162 & 0.1181 & 0.1131 \\
Tier 1 capital ratio & 0.7536 & 0.8541 & 0.0145 & 0.0139 \\
Capital structure & 0.4634 & 0.9526 & 0.0186 & 0.0162 \\
Disc Interest rates & 0.0050 & 0.0038 & 0.0207 & 0.0200 \\
\hline
\end{tabular}

In this given table results showed that during the years of after global financial crises there are more significant effects of independent variables on the loan made to consumers because of the change in Basel accord. As before the financial crises of 20072008, Basel II was used for these discussed independent variables but because of unstable economic conditions during the financial crises Basel III was implemented in which these ratios were changed for the financial stability in economy.

\begin{tabular}{lcc}
\hline & $\begin{array}{c}\text { Before financial } \\
\text { crises (2001-2008) }\end{array}$ & $\begin{array}{c}\text { After financial crises } \\
(\mathbf{2 0 0 9 - 2 0 1 7 )}\end{array}$ \\
\hline R-squared & 0.725455 & 0.851206 \\
Prob(F-statistic) & 0.000000 & 0.000000 \\
\hline
\end{tabular}

By comparing, the results showed that before financial crises discounted interest rates have more significant impact on the loan made to consumers. It also declares that there are seventy two percent changes in lending to consumers are due to these discussed independent variables. Probability value shows that there is a significant impact of independent variables on the lending to consumers before global financial crises. So, we accept the alternative hypothesis $\left(\mathbf{H}_{\mathbf{1}}\right)$ that there is a significant impact of bank capital, capital structure and monetary policy on loan made to consumers and reject the null hypothesis $\left(\mathrm{H}_{0}\right)$ before the global financial crises. 
After financial crises discounted interest rates, capital structure and tier 1 capital ratio have more significant impact on the loan made to consumers. It also declares that there are eighty five percent changes in lending to consumers are due to these discussed independent variables. Probability value shows that there is a significant impact of independent variables on the lending to consumers So, we accept the alternative hypothesis $\left(\mathbf{H}_{\mathbf{1}}\right)$ that there is a significant impact of bank capital, capital structure and monetary policy on loan made to consumers and reject the null hypothesis $\left(\mathrm{H}_{0}\right)$ after global financial crises.

Table 8: Loan to Commercial \& Industrial

\begin{tabular}{lcccc}
\hline \multirow{2}{*}{ Variables } & \multicolumn{2}{c}{$\begin{array}{c}\text { Before financial crises } \\
(\mathbf{2 0 0 1 - 2 0 0 8})\end{array}$} & \multicolumn{2}{c}{$\begin{array}{c}\text { After financial crises } \\
(\mathbf{2 0 0 9 - 2 0 1 7})\end{array}$} \\
\cline { 2 - 5 } & $\begin{array}{c}\text { Fixed } \\
\text { effect } \\
\text { Model }\end{array}$ & $\begin{array}{c}\text { Random } \\
\text { effect } \\
\text { Model }\end{array}$ & $\begin{array}{c}\text { Fixed } \\
\text { effect } \\
\text { Model }\end{array}$ & $\begin{array}{c}\text { Random } \\
\text { effect Model }\end{array}$ \\
& 0.3958 & 0.3658 & 0.1008 & 0.0992 \\
Capital adequacy ratio & 0.6708 & 0.5727 & 0.0356 & 0.0324 \\
Tier 1 capital ratio & 0.6075 & 0.9600 & 0.0055 & 0.0078 \\
Capital structure & 0.0581 & 0.0509 & 0.0002 & 0.0002 \\
Disc Interest rates & & &
\end{tabular}

In this given table results showed that during the years of after global financial crises there are more explanatory effects of independent variables on the loan made to commercial \& industrial sector because of the change in Basel accord. As before the financial crises of 2007-2008, Basel II was used for these discussed independent variables but because of unstable economic conditions during the financial crises Basel III was implemented in which these ratios were changed for the financial stability in economy.

\begin{tabular}{lcc}
\hline & $\begin{array}{c}\text { Before financial crises } \\
(\mathbf{2 0 0 1 - 2 0 0 8 )}\end{array}$ & $\begin{array}{c}\text { After financial crises } \\
(\mathbf{2 0 0 9 - 2 0 1 7 )}\end{array}$ \\
\hline R-squared & 0.806978 & 0.881436 \\
Prob(F-statistic) & 0.000000 & 0.000000 \\
\hline
\end{tabular}

By comparing, the results showed that before financial crises discounted interest rates have more significant impact on the loan made to commercial \& industrial sector. It also declares that there are eighty percent changes in lending to commercial $\&$ industrial sector are due to these discussed independent variables. Probability value shows that there is a significant impact of independent variables on the lending to commercial \& industrial sector before the global financial crises. So, we accept the alternative hypothesis $\left(\mathbf{H}_{1}\right)$ that there is significant impact of bank capital, capital structure and monetary policy on loan made to commercial \& industrial sector and reject the null hypothesis $\left(\mathrm{H}_{0}\right)$ before financial crises.

After financial crises discounted interest rates, capital structure and tier 1 capital ratio have more significant impact on the loan made to commercial \& industrial sector. It also declares that there are eighty eight percent changes in lending to commercial \& industrial sector are due to these discussed independent variables. Probability value shows that there is a significant impact of independent variables on the lending to commercial \& industrial sector after the global financial crises. So, we accept the alternative hypothesis $\left(\mathbf{H}_{1}\right)$ that there is significant impact of bank capital, capital structure and monetary policy on loan made to commercial $\&$ industrial sector and reject the null hypothesis $\left(\mathrm{H}_{0}\right)$ after financial crises.
Table 9: Loan to Real Estate

\begin{tabular}{lcccc}
\hline \multirow{2}{*}{ Variables } & \multicolumn{2}{c}{$\begin{array}{c}\text { Before financial crises } \\
(\mathbf{2 0 0 1 - 2 0 0 8 )}\end{array}$} & \multicolumn{2}{c}{$\begin{array}{c}\text { After financial crises } \\
(\mathbf{2 0 0 9 - 2 0 1 7})\end{array}$} \\
\cline { 2 - 5 } & $\begin{array}{c}\text { Fixed effect } \\
\text { Model }\end{array}$ & $\begin{array}{c}\text { Random } \\
\text { effect } \\
\text { Model }\end{array}$ & $\begin{array}{c}\text { Fixed } \\
\text { effect } \\
\text { Model }\end{array}$ & $\begin{array}{c}\text { Random } \\
\text { effect Model }\end{array}$ \\
\hline Capital adequacy ratio & 0.9083 & 0.8596 & 0.4871 & 0.5575 \\
Tier 1 capital ratio & 0.7615 & 0.9340 & 0.4085 & 0.4398 \\
Capital structure & 0.5603 & 0.1933 & 0.0523 & 0.0312 \\
Disc Interest rates & 0.0304 & 0.0266 & 0.0317 & 0.0255 \\
\hline
\end{tabular}

In this given table results showed that during the years of after global financial crises there are more explanatory effects of independent variables on the loan made to real estate because of the change in Basel accord. As before the financial crises of 20072008, Basel II was used for these discussed independent variables but because of unstable economic conditions during the financial crises Basel III was implemented in which these ratios were changed for the financial stability in economy.

\begin{tabular}{lcc}
\hline & $\begin{array}{c}\text { Before financial crises } \\
(\mathbf{2 0 0 1 - 2 0 0 8 )}\end{array}$ & $\begin{array}{c}\text { After financial crises } \\
(\mathbf{2 0 0 9 - 2 0 1 7 )}\end{array}$ \\
\hline R-squared & 0.737172 & 0.852579 \\
Prob(F-statistic) & 0.000000 & 0.000000 \\
\hline
\end{tabular}

By comparing, the results showed that before financial crises discounted interest rates have more significant impact on the loan made to real estate. It also declares that there are seventy three percent changes in lending to real estate are due to these discussed independent variables. Probability value shows that there is a significant impact of independent variables on the lending to real estate before the global financial crises. So, we accept the

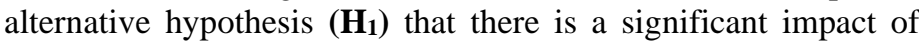
bank capital, capital structure and monetary policy on loan made to real estate and reject the null hypothesis $\left(\mathrm{H}_{0}\right)$ before financial crises.

After financial crises discounted interest rates and capital structure have more significant impact on the loan made to real estate. It also declares that there are eighty five percent changes in loan made to real estate are due to these discussed independent variables. Probability value shows that there is a significant impact of independent variables on the lending to real estate after the global financial crises. So, we accept the alternative hypothesis $\left.\mathbf{~}_{\mathbf{1}}\right)$ that there is a significant impact of bank capital, capital structure and monetary policy on loan made to real estate and reject the null hypothesis $\left(\mathrm{H}_{0}\right)$ after financial crise

T-test is used to determine that there is a possible significant difference between lending behavior of banks before and after global financial crises.

Table 10: T-Test for lending to consumers

\begin{tabular}{lcccc}
\hline & Mean & N & $\begin{array}{c}\text { Std. } \\
\text { Deviation }\end{array}$ & $\begin{array}{c}\text { Std. Error } \\
\text { Mean }\end{array}$ \\
\hline Loan to consumers before crises & 105331.4250 & 80 & 107499.62406 & 12018.82335 \\
Loan to consumers after crises & 155734.0250 & 80 & 112244.15368 & 12549.27788 \\
\hline
\end{tabular}

In this paired sample statistics table, the mean of loan made to consumers before crises is 105331.4250 and after financial crises is 155734.0250 . The standard deviation before financial crises is 107499.62406 and the after financial crises 112244.15368. This table shows that mean of loan made to consumers after financial crises is greater than the mean of loan made to consumers before financial crises, because of this we can conclude that there was a positive and significant impact of bank capital, capital structure and monetary policy on the loan made to consumers after global financial crises because of the change in Basel accord. 


\begin{tabular}{|c|c|c|c|c|c|c|c|c|}
\hline & \multicolumn{5}{|c|}{$\begin{array}{l}\text { Paired Differences } \\
\end{array}$} & \multirow[t]{3}{*}{$\mathbf{t}$} & \multirow[t]{3}{*}{ Df } & \multirow{3}{*}{ Sig } \\
\hline & \multirow[t]{2}{*}{ Mean } & \multirow[t]{2}{*}{$\begin{array}{c}\text { Std. } \\
\text { Deviation }\end{array}$} & \multirow[t]{2}{*}{$\begin{array}{c}\text { Std. } \\
\text { Error } \\
\text { Mean }\end{array}$} & \multicolumn{2}{|c|}{$\begin{array}{l}\text { 95\% Confidence } \\
\text { Interval of the } \\
\text { Difference }\end{array}$} & & & \\
\hline & & & & Lower & Upper & & & \\
\hline $\begin{array}{l}\text { Loan to consumers } \\
\text { before crises - Loan to } \\
\text { consumers after crises }\end{array}$ & -50402.60 & 101751.33 & 11376.145 & -73046.25 & -27758.94 & -4.43 & 79 & .000 \\
\hline
\end{tabular}

In this given table, the T-test values of loan made to consumers is less than the critical value $(5 \%)$ so we accept the alternative hypothesis $\left(\mathbf{H}_{\mathbf{1}}\right)$ according to which there is a statistically significant difference between the loan made to consumers before financial crises and loan made to consumers after financial crises and reject the null hypothesis $\left(\mathrm{H}_{0}\right)$.

Table 11: T-test for lending to commercial \& industrial sector

\begin{tabular}{lcccc}
\hline & Mean & N & $\begin{array}{c}\text { Std. } \\
\text { Deviation }\end{array}$ & Std. Error Mean \\
\hline $\begin{array}{l}\text { Loan to commercial and industrial } \\
\text { before crises }\end{array}$ & 138661.85 & 80 & 164284.58 & 18367.57 \\
$\begin{array}{l}\text { Loan to commercial and industrial } \\
\text { after crises }\end{array}$ & 218294.90 & 80 & 210344.48 & 23517.22 \\
\hline Inthen & & & & \\
\hline
\end{tabular}

In this paired sample statistics table, the mean of loan made to commercial \& industrial sector before crises is 138661.8500 and the mean after financial crises is 218294.9000 . The standard deviation before financial crises is 164284.58150 and after financial crises 210344.48877. This table shows that mean of loan made to commercial \& industrial sector after financial crises is greater than the mean of loan made to commercial \& industrial sector before financial crises, because of this we can conclude that there was a positive and significant impact of bank capital, capital structure and monetary policy on the loan made to commercial \& industrial sector after global financial crises because of the change in Basel accord.

\begin{tabular}{|c|c|c|c|c|c|c|}
\hline & \multicolumn{5}{|c|}{ Paired Differences } & \multirow[t]{3}{*}{ t df Sig } \\
\hline & \multirow[t]{2}{*}{ Mean } & \multirow[t]{2}{*}{$\begin{array}{c}\text { Std. } \\
\text { Deviation }\end{array}$} & \multirow[t]{2}{*}{$\begin{array}{l}\text { Std. Error } \\
\text { Mean }\end{array}$} & \multicolumn{2}{|c|}{$\begin{array}{l}95 \% \text { Confidence } \\
\text { Interval of the } \\
\text { Difference }\end{array}$} & \\
\hline & & & & Lower & Upper & \\
\hline $\begin{array}{l}\text { Loan to } \\
\text { commercial and } \\
\text { industrial } \\
\text { before crises - } \\
\text { Loan to } \\
\text { commercial and } \\
\text { industrial after } \\
\text { crises }\end{array}$ & -79633.05 & 156451.05 & 17491.75 & -114449.52 & -44816.57 & $\begin{array}{lll}-4.5 & 79.000\end{array}$ \\
\hline
\end{tabular}

In this given table, the T-test values of loan made to commercial $\&$ industrial is less than the critical value (5\%) so we accept the alternative hypothesis $\left(\mathbf{H}_{\mathbf{1}}\right)$ according to which there is a statistically significant difference between loan made to commercial \& industrial sector before financial crises and the loan made to commercial \& industrial sector after financial crises and reject the null hypothesis $\left(\mathrm{H}_{0}\right)$.

Table 12: T-Test for lending to Real estate

\begin{tabular}{lcccc}
\hline & Mean & N & $\begin{array}{c}\text { Std. } \\
\text { Deviation }\end{array}$ & $\begin{array}{c}\text { Std. Error } \\
\text { Mean }\end{array}$ \\
\hline $\begin{array}{l}\text { Loan to real estate before } \\
\text { financial crises }\end{array}$ & 105837.38 & 80 & 107090.37 & 11973.06 \\
$\begin{array}{l}\text { Loan to real estate after financial } \\
\text { crises }\end{array}$ & 180719.31 & 80 & 148195.78 & 16568.79 \\
\hline
\end{tabular}

In this paired sample statistics table, the mean of the loan made to real estate before financial crises 105837.3875 and the mean after financial crises is 180719.3125 . The standard deviation before financial crises is 107090.37101 and after financial crises 148195.78925. This table shows that mean of loan made to real estate after financial crises is greater than the mean of loan made to real estate before financial crises, because of this we can conclude that there was a positive and significant impact of bank capital, capital structure and monetary policy on the loan made to real estate after global financial crises because of the change in Basel accord.

\begin{tabular}{|c|c|c|c|c|c|c|c|c|}
\hline & \multicolumn{5}{|c|}{ Paired Differences } & \multirow{3}{*}{$-\mathbf{T}$} & \multirow[t]{3}{*}{ Df } & \multirow[t]{3}{*}{ Sig. } \\
\hline & \multirow[t]{2}{*}{ Mean } & \multirow[t]{2}{*}{$\begin{array}{l}\text { Std. } \\
\text { Deviation }\end{array}$} & \multirow[t]{2}{*}{$\begin{array}{l}\text { Std. } \\
\text { Error } \\
\text { Mean }\end{array}$} & \multicolumn{2}{|c|}{$\begin{array}{l}\text { 95\% Confidence } \\
\text { Interval of the } \\
\text { Difference }\end{array}$} & & & \\
\hline & & & & Lower & Upper & & & \\
\hline $\begin{array}{l}\text { Loan to real estate } \\
\text { before financial crises } \\
\text { - Loan to real estate } \\
\text { after financial crises }\end{array}$ & -74881.9 & 136716.0 & 15285.3 & - 105306.5 & -44457.2 & -4.8 & 79 & .000 \\
\hline
\end{tabular}

In this given table, the T-test values of loan made to real estate is less than the critical value $(5 \%)$ so we accept the alternative hypothesis (H1) according to which there is a statistically significant difference between loan made to real estate before financial crises and the loan made to real estate after global financial crises and reject the null hypothesis $\left(\mathrm{H}_{0}\right)$.

\section{Conclusion}

From analysis of before and after global financial crises, the results of the accepted (Fixed effect) model by Hausman test, showed that there is a positive and significant impact of the bank capital, capital structure and monetary policy on the loan made to real estate, loan made to consumers and loan made to commercial and industrial sector. But the significance level/explanatory powers of these independent variables have been increased with the change of sixteen percent in R-squared value after the global financial crises. T-test results of the comparative analysis of before and after global financial crises showed that there is a statistically significant difference between lending to real estate, lending to consumers and lending to commercial \& industrial sector before and after the global financial crises due to the implementation of Basel III.

This research would be interest of wider audience because of the following

- This study has practically contributed through its comparative analysis of lending behavior of before and after financial crises that banks can stay strong in bad economic conditions with the help of the Basel Accord.

- This research would be beneficial for the commercial banks to make a sound decision while lend to their borrowers with having different capital structure within the different monetary policy.

- This study is useful for the borrowers those want to borrow money from banks for different purposes (to increase their business of Real estate or commercial and industrial, for household, or to invest in money market etc).

- This research provides guidance regarding the role of their capital structure (percentage of equity and debt in capital) to fulfill the capital requirements according the regulators and to increase the positive change in their lending behavior.

\section{Recommendations of Research}

For future study the new researchers can expand this study to the banks of emerging countries or by taking the other banks of USA. They can take the different time horizon (only take the years of post-financial crises) or they can use the monthly data of these selected banks to better analyze the impact of banks capital, capital structure and monetary policy on their lending behavior. 


\section{References}

Schwert, M. (2018). Bank capital and lending relationships. The Journal of Finance, 73(2), 787-830

Košak, M., Li, S., Loncarski, I., \& Marinč, M. (2015). Quality of bank capital and bank lending behavior during the global financial crisis. International Review of Financial Analysis, 37(C), 168-183.

Karmakar, S., \& Mok, J. (2015). Bank capital and lending: An analysis of commercial banks in the United States. Economics Letters, 128(C), 21-24.

Kashyap, A. K., Stein, J. C., \& Hanson, S. (2010). An analysis of the impact of 'substantially heightened'capital requirements on large financial institutions. Booth School of Business, University of Chicago, mimeo, 2.

Bridges, J., Gregory, D., Nielsen, M., Pezzini, S., Radia, A., \& Spaltro, M. (2014). The impact of capital requirements on bank lending.

Berrospide, J. M., \& Edge, R. M. (2010). The Effects of Bank Capital on Lending: What Do We Know, and What Does It Mean? International Journal of Central Banking, 6(34), 1-50.

Swamy, V. (2015). Capital and liquidity requirements: impact on bank lending spreads. International Journal of Banking, Accounting and Finance, 6(1), 53-72.

Osborne, M., Fuertes, A. M., \& Milne, A. (2017). In good times and in bad: Bank capital ratios and lending rates. International Review of Financial Analysis, 100(51), 102-112.

Carlson, M., Shan, H., \& Warusawitharana, M. (2013). Capital ratios and bank lending: A matched bank approach. Journal of Financial Intermediation, 22(4), 663-687.

Drehmann, M., \& Gambacorta, L. (2012). The effects of countercyclical capital buffers on bank lending. Applied economics letters, 19(7), 603-608.

Park, S. (2006). Effects of stock mispricing and regulatory capital constraints on bank lending. Journal of Economics and Business, 58(2), 137-152.

Akinyomi, O. J., \& Enahoro, J. A. (2014). A post consolidation analysis of recapitalization and lending behaviour in Nigerian banking sector. International Journal of Research in Social Sciences, 4(4), 190.

Francis, W., \& Osborne, M. (2009). Bank regulation, capital and credit supply: Measuring the Impact of Prudential Standards (No. 36). Financial Services Authority.

Labonne, C., \& Lame, G. (2014). Credit Growth and Bank Capital Requirements: Binding or Not? Banque de France.

Furfine, C. (2001). Bank portfolio allocation: The impact of capital requirements, regulatory monitoring, and economic conditions. Journal of Financial Services Research, 20(1), 3356.

Olokoyo, F. O. (2011). Determinants of commercial banks' lending behavior in Nigeria. International journal of financial research, 2(2), 61-72.

Olusanya, S. O., Oyebo, A. O., \& Ohadebere, E. C. (2012). Determinants of lending behaviour of commercial banks: Evidence from Nigeria, a co-integration analysis (19752010). Journal of Humanities and Social science, 5(5), 71-80.
Maurin, L., \& Toivanen, M. (2012). Risk, capital buffer and bank lending: a granular approach to the adjustment of euro area banks (No. 1499). European Central Bank.

Jokipii, T., \& Milne, A. (2008). The cyclical behaviour of European bank capital buffers. Journal of banking \& finance, 32(8), 1440-1451.

Chu, Y., Zhang, D., \& Zhao, Y. E. (2019). Bank capital and lending: Evidence from syndicated loans. Journal of Financial and Quantitative Analysis, 54(2), 667-694.

Kim, D., \& Sohn, W. (2017). The effect of bank capital on lending: Does liquidity matter? Journal of banking and finance, 77(4), 95-107.

Kishan, R., \& Opiela, T. P. (2000). Bank Size, Bank Capital, and the Bank Lending Channel. Journal of Money, Credit \& Banking, 32(1), 121.

Gambacorta, L., \& Mistrulli, P. E. (2004). Does bank capital affect lending behavior? Journal of Financial intermediation, 13(4), 436-457.

Narmeen, S., Saba, I., Kouser, R., \& Khurram, H. (2018). Why Banks Need Adequate Capital Adequacy Ratio? A Study of Lending \& Deposit Behaviors of Banking Sector of Pakistan. Journal of Accounting and Finance in Emerging Economies, 4(1), 1-16.

De Nicolò, G. (2015). Revisiting the impact of bank capital requirements on lending and real activity. Available at SSRN 2688110

Miki, H. (2017). Bank capital and bank lending in the Indonesian banking sector (No. 662). Institute of Developing Economies, Japan External Trade Organization (JETRO).

Gustavsson, F., \& Taheri, J. (2017). The Effect of Capital Requirements on Bank Lending to Small and Medium-Sized Enterprises.

Lepetit, L., Saghi-Zedek, N., \& Tarazi, A. (2015). Excess control rights, bank capital structure adjustments, and lending. Journal of Financial Economics, 115(3), 574-591.

Fernández-Méndez, C., \& González, V. M. (2019). Bank ownership, lending relationships and capital structure: Evidence from Spain. BRQ Business Research Quarterly, 22(2), 137-154.

Cebenoyan, A. S., \& Strahan, P. E. (2004). Risk management, capital structure and lending at banks. Journal of Banking \& Finance, 28(1), 19-43.

Leary, M. T. (2009). Bank loan supply, lender choice, and corporate capital structure. The Journal of Finance, 64(3), 1143-1185.

Allen, F., Carletti, E., \& Marquez, R. (2011). Credit market competition and capital regulation. The Review of Financial Studies, 24(4), 983-1018.

Ladime, J., Sarpong-Kumankoma, E., \& Osei, K. A. (2013). Determinants of bank lending behavior in Ghana. Journal of Economics and Sustainable Development, 4(17), 42-47.

Akhtar, Y., Kayani, G. M., \& Yousaf, T. (2019). The Effects of Regulatory Capital Requirements and Ownership Structure on Bank Lending in Emerging Asian Markets. Journal of Risk and Financial Management, 12(3), 1-20. 
Wu, L., \& Yue, H. (2009). Corporate tax, capital structure, and the accessibility of bank loans: Evidence from China. Journal of Banking \& Finance, 33(1), 30-38.

Berger, A. N., \& Udell, G. F. (2002). Small business credit availability and relationship lending: The importance of bank organisational structure. The economic journal, 112(477), F32F53.

Amidu, M., \& Hinson, R. (2006). CREDIT RISK, CAPITAL STRUCTURE AND LENDING DECISIONS OF BANKS IN GHANA. Publishing Company" Business Perspectives" Banks and Bank Systems International Research Journal, 93.

Pennacchi, G. G. (1988). Loan sales and the cost of bank capital. The Journal of Finance, 43(2), 375-396.

Zicchino, L. (2005). A model of bank capital, lending and the macroeconomy: Basel I versus Basel II. Bank of England. Quarterly Bulletin, 45(3), 377.

Shaw, M. F., Chang, J. J., \& Chen, H. J. (2013). Capital adequacy and the bank lending channel: Macroeconomic implications. Journal of Macroeconomics, (36), 121-137.

Disyatat, P. (2011). The bank lending channel revisited. Journal of money, Credit and Banking, 43(4), 711-734.

Gambacorta, L. (2005). Inside the bank lending channel. European Economic Review, 49(7), 1737-1759.

Cottarelli, C., \& Kourelis, A. (1994). Financial structure, bank lending rates, and the transmission mechanism of monetary policy. Staff Papers, 41(4), 587-623.
Ayuso, J., Pérez, D., \& Saurina, J. (2004). Are capital buffers procyclical? Evidence from Spanish panel data. Journal of financial intermediation, 13(2), 249-264.

Altunbas, Y., De Bondt, G., \& Marques-Ibanez, D. (2004). Bank capital, bank lending, and monetary policy in the euro area. Kredit und Kapital.

Chami, R., \& Cosimano, T. F. (2010). Monetary policy with a touch of Basel. Journal of Economics and Business, 62(3), 161175.

Gambacorta, L., \& Shin, H. S. (2018). Why bank capital matters for monetary policy. Journal of Financial Intermediation, 35, 17-29.

Van den Heuvel, S. (2006, December). The Bank Capital Channel of Monetary Policy. In 2006 Meeting Papers (No. 512). Society for Economic Dynamics.

Sengonul, A., \& Thorbecke*, W. (2005). The effect of monetary policy on bank lending in Turkey. Applied Financial Economics, 15(13), 931-934.

Thakor, A. V. (1996). Capital requirements, monetary policy, and aggregate bank lending: theory and empirical evidence. The Journal of Finance, 51(1), 279-324.

Xiong, Q. (2013). The role of the bank lending channel and impacts of stricter capital requirements on the Chinese banking industry. BOFIT Discussion Papers, 2013(7), 4.

Ghosh, S. (2008). Capital requirements, bank behavior and monetary policy: A theoretical analysis with an empirical application to India. Indian Economic Review, 43(2), 205-227. 